\title{
Dinmukhammed Ametbek, İran Vakıfları: Dış Politika Arkasındaki Yumuşak Güç. Ankara: Astana Yayınları, (2021), ss. 180.
}

Nurhak GÜREL ${ }^{1}$

İran'da devrim sonrası oluşan yeni siyasal sistem içerisinde, vakıflar (Bonyad) ile yeni askeri/güvenlik temelli kurumlar ağı birbirilerine bağlıdırlar. Devrim Muhafızları Ordusu (DMO) ile vakıfların ekonomi ve dış politika alanında kurdukları bağlar, bunun en güncel örneğini teşkil etmektedir. Her ikisi de Velayet-i Fakih'ten elde ettikleri meşruiyet ile güçlü birer siyasal aktör olma özelliklerini korumuşlardır. Devrim sonrası süreçte, ekonomide ve özellikle savunma sanayisinde elde ettikleri güç, vakıfların dış politika süreçlerindeki etkinliklerini attırmalarını sağlamıştır. Böylece iç politikanın ötesine geçen bağlantılara ve çıkarlara sahip oldukları bilinmektedir. İran çalışmaları açısından tartışılması gereken vakıfların bu güçlü pozisyonuna yönelik henüz kapsamlı bir inceleme kaleme alınmamıştı. Dinmukhammed Ametbek'in, vakıfların dış politikada yumuşak güç kullanımı ile ilişkisine odaklanarak kaleme aldığı İran Vakıfları: Dış Politika Arkasındaki Yumuşak Güç kitabı, bu boşluğu doldurabilecek önemli katkılar sağlıyor.

Kitabın ana odağında, İran'daki vakıfların İran dış politikasında mevcut yumuşak güç politikasına nasıl etki ettikleri yer almaktadır. Vergi ödemekten muaf ve diğer kamu kuruluşlarının aksine denetime tabi tutulmayan vakıflar birer devlet dışı aktör olarak nitelendiriliyor. Yazara göre her ne kadar İran, "devrim ihracı" söyleminden vazgeçmiş görünse de vakıflar, muhafazakâr kanadın devrim ihracını gündemde tutmasında önemli birer araçtırlar. Buradan yola çıkan yazar içerikte konuyu altı bölümde ele almaktadır. Fakat bu altı bölüm temelde iki meseleye odaklanıyor: yumuşak gücün dış politika açısından önemi ve kurumsal yapıları, faaliyet alanları, yurtdışındaki etkinlikleriyle vakıfların İran dış politikasındaki yeri. İlk bölüm yumuşak güç ve devrim ilişkisini tartışmak üzere bir kavramsal çerçeve ile başlıyor. Yumuşak güç kavramının Uluslararası İlişkiler disiplininde, dış politika açısından öneminin incelendiği ilk başlıklarda devrim ile yumuşak güç arasında kurulan bağlantı dikkat çekmektedir. Yazara göre dini terminolojideki "misyonerlik", "tebliğ" ve "davet" gibi kavramlar devrim olgusunun yumuşak güç boyutuna işret etmektedir. İran'da ise rejim bazı kültürel, siyasal ve dini değerler üzerinden yumuşak güç politikasını belirlemektedir. Burada "Fars dili ve kültürü", "İslam Birliği" söylemi ve "dini demokrasi" gibi değerler Türk dünyası, Müslüman Hint dünyası ve Arap dünyası açısından cazibe oluştururken, İran'ın yumuşak güç elde etmesinde birer araç olmaktadırlar (s17-18).

İkinci bölümde vakıfların faaliyetleri, ekonomik güçleri ve etki alanlarıyla İran'daki konumuna yer verilmektedir. Devrimden sonra vakıflar hem iç politikada rejimin güçlenmesinde hem de dış politikada yumuşak güç elde edilmesinde önemli roller üstlendiler. Devrimden önce bu vakıflar Fars milliyetçiliğine hizmet eden kurumlardı. Devrim ile beraber İran İslam Cumhuriyeti'nin ideolojik söylemlerinin propagandasında kilit rol oynayan birer kurum haline gelmişlerdir. Devrim öncesi ile devrim sonrası vakıfların rolü üzerine yapılan bu kıyaslamayla yazar, vakıfların bugün asıl amaçları dışında bir işleyişe sahip olup İran'da rejimin ideolojik amaçları açısından nasıl araçsallaştırıldıklarını vurgulamaktadır (s.20-23). Bu anlamda İran'da etki gücü yüksek olan vakıfların hepsinin ortak bir amaç etrafında faaliyet gösterdiklerine dikkat çekmektedir. Bu amacın yumuşak gücün şekillenmesiyle doğrudan bir bağlantısı olduğu anlaşılıyor. Örneğin, insani yardım amaçlı faaliyetler, ağırlıklı olarak Tacikistan, Afganistan ve Irak'ta görülmektedir. Bunun dışında İran'daki vakıflar; ekonomik yatırımlar, kültür, sanat, eğitim ve medyaya kadar birçok alanda faaliyet gösterebilmektedirler (s.27-39).

\footnotetext{
${ }^{1}$ Doktora Adayı Araştırma Görevlisi, Sakarya Üniversitesi, Siyasal Bilgiler Fakültesi/Uluslararası İlişkiler Bölümü, Sakarya, Türkiye, ORCID: 0000-0002-9763-3108, nurhakgurel@gmail.com
} 
Kitabın üçüncü, dördüncü ve beşinci bölümlerinde, İran dış politikasında önemli rolller üstlenen vakıflar kurumsal yapıları ve faaliyet alanlarına göre üç başlıkta incelemektedir: insani yardım, kültürel ve dini vakıflar. Ezilmişler ve Engelliler Vakfı, İmam Humeyni Yardımlaşma Komitesi, Bereket Vakfı gibi insani yardım vakıfları, çeşitli ülkelerde yürüttükleri insani yardım faaliyetleri ile bir taraftan İran açısından olumlu bir imaj oluştururken diğer taraftan İran'ın bu ülkelerde nüfuz elde etmesinde başarılı olmuşlardır. Vakıfların İran ekonomisindeki güçlerine dair en iyi örnek; Bonyad-i Mustezefan olarak bilinen vakıftır. İran'da Ulusal İran Petrol Şirketi'nden sonra ikinci büyük ticari güç olması aslında vakıfların İran'daki ekonomideki gücü açısından önemli bir gösterge olmuştur. Bununla birlikte aynı vakıf yolsuzluk, rüşvet, mali bilançoda kapalılık ve rant gibi eleştirilerin odağı haline gelebilmiştir. Kitabın odaklandığı yumuşak güç açısından da işlevi yüksek bir vakıf olarak değerlendiriliyor. Çünkü bu vakıf, devrim anlayışının yurt dışına ihraç edilmesine yönelik ticari ve ideolojik girişimlerde bulunmaktadır (s.42-54). Kitapta kültürel vakıflar başlığı altında ele alınan Saadi Vakfı, Farabi Vakfı, İslam Tebliği Örgütü, Kutsal Rezevi Külliyesi gibi kurumlar; "Şii tarih”, "İran uygarlığını temsil eden dil ve edebiyat" gibi kültürel unsurlar üzerinden faaliyetlerini yürütmektedirler. Dünyada birçok ülkede temsilcilikleri, kültür merkezleri ve dil kursları gibi unsurlar üzerinden varlık gösteren bu vakıflar, İran kültürel değer ve ilkelerini dünyaya tanıtmada etkin olmuşlardır. Böylece İran'ın yumuşak güç araçları arasında en ön cephelerde yer aldığ dile getiriliyor (s.96-110). Beşinci bölümde dini vakıflar; ekonomik güçleri, hedefleri ve amaçları bağlamında detaylı bir incelemeye tabi tutuluyor. Bu başlık altında ele alınan vakıfların, İran dini liderinin söylemlerinin dışarıya tanıtılmasında ve dış politika hedeflerinin uygulamasında önemi birer aracı rolü üstlendikleri anlaşılmaktadır. Bu vakıfların dışarda din adamları ve eğitim kurumlarıyla kurdukları ağlarla hedef aldıkları kitleye ulaşmada zorluk çekmemeleri, dış politikada yumuşak gücün elde edilmesi açısından önemli birer araç olduklarını kanıtlar niteliktedir (s.112-124).

Altıncı bölümde, İran'da "İslam Birliği" söyleminin rejim tarafından devlet çıarları doğrultusunda, özellikle dış politikada nasıl kullanıldığı ele alınıyor. İslami Kültür ve İletişim Kurumu, Dünya Ehlibeyt Kurultayı, Dünya Mezhepler Arasında Yakınlaşma Kurultayı gibi girişimler, kamu diplomasinin kurucuları olarak ele alınırken, yumuşak güç açısından da işlevsellikleri ön plana çıkarılıyor. Nitekim yazara göre, bu vakıflar daha önce ele alınan tüm vakıfların ötesinde, İran yumuşak gücünün asıl yürütücüleridirler (s.126). İran'ın yumuşak güç elde etmede "İslam Devrimi" söylemlerini araçsallaştırması, İran ve İslam kültürünün birbirinden ayrı unsur oldukları anlamına gelmiyor. Yazar bu tespitten hareketle, İran'ın yumuşak gücündeki etkinliğini üçe ayırıyor. Birinci düzlemde İslam öncesi İran medeniyeti ve Fars dilinin şekillendirdiği bir "İran Medeniyeti" ön plana çıkmaktadır. Yazarın seküler olarak nitelediği bu söylem, genel anlamda tüm dış dünyayı hedefleyen bir kapsayıcıllğa sahiptir. İkinci düzlemde "İslam Birliği" söylemine yer veriliyor. Bu söylem ile İran'a, İslam dünyasında birlik için çalışan bir ülke olma özelliği atfedilmiştir. Bu yönüyle özellikle Sünni Müslüman dünyasında karşılık bulma gibi bir amaç gözetilmektedir. Üçüncü düzlemde ise "Şii İslam Dünyası"nı kapsayan yumuşak güç unsurları yer alıyor (s.127). Böylece önceki iki düzlemin üçüncüye zemin hazırladığı sonucuna varılmaktadir.

Sonuç olarak kitap, İran'daki vakıfları ve dış politikadaki güçlerini anlayabilmek için okunmaya değerdir. Üç noktada özetleyebileceğimiz katkılarıyla bunu ispatlamaktadır. Birincisi; kitap, dış politika çalışmalarında "devletler hangi araçlar üzerinden ve nasıl yumuşak güç elde ederler?" tartışmasının kavramsal çerçevesini çizerek, vakıflar ve dış politika ilişkisinin teorik zeminini sunmaktadır. İkincisi, İran'daki vakıfları detaylı bir incelemeye tabi tutarak; amaçları, faaliyetleri ve bağlantıları ile ilgili önemli bir sınıflandırma sunmaktadır. Üçüncüsü, yazarın farklı dillerde (Türkçe, Farsça, İngilizce, Rusça) yazılan birçok kaynaktan elde ettiği verilerle konuyu ele alması, içerik ve kaynakça zenginliğini göstermektedir. Bu katkısıyla, akademik ve akademi dışı çevrelerde başvurulabilecek önemli bir çalışma niteliğindedir. Özellikle konu ile ilgilenen İran çalışmışlarındaki araştırmacıların işini önemli ölçüde kolaylaştıracaktır.

Diğer taraftan, kitap, argümantasyon açısından eleştiriye tabi tutulabilir. Kavramsal çerçeve ile ilgili bölümde, yazar yumuşak gücün sert güce göre devletlerin dış politikalarında daha etkili olduğunu savunmaktadır. Bununla ilgili II. Dünya Savaşı sonrasında Almanya'nın yumuşak gücü sayesinde "tek kurşun dahi sıkmadan Doğu Avrupa'yı entegre ettiği (s.13)" şeklinde bir argüman ileri sürmektedir. Başka yerde "zihinleri kontrol etme" ile yumuşak güç arasında iddialı bir bağlantı kurulmaktadır. Bizce bu argümanlar başlı başına disiplin içerisinde tartı̧̧ılması gerekir. Kitapta buna yönelik bir tartışma yapılmamış olması veya ilgili başka tartışmalara atıfta bulunulmaması, argümanların işlenişini 
zayıflatmaktadır. Soğuk Savaş'ın temelinde iddialı bir yumuşak güç savaşının olduğunu dile getiren yazarın, bu savaşı "Yumuşak Güç Savaşı (s.15)" olarak adlandırması da aynı eleştiriden nasibini alabilir. 